\title{
Art History and other Stories
}

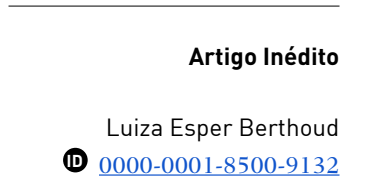

keywords: Art Criticism; Art History; Philosophy of Art

palavras-chave: crítica de arte; história da arte; filosofia da arte

*Universidade da Califórnia, Estados Unidos

DOI: $10.11606 /$ issn.2178-0447. ars.2020.162471

\author{
História da Arte e outras histórias \\ Historia del Arte y otras historias
}


A partir del análisis de trabajo erróneo de la crítica del arte, Art History and other stories un ensayo de Goethe que intenta reimaginar una escultura antigua desparecida, demostro la dificultad de la Historia del Arte, en cuanto disciplina, de conceptualizar la experiencia de creación artística y abordo cómo es posible responder a eso. Reexamino la relación entre el hacer artístico y la apreciación del arte con base en ideas cómo el entendimiento de Aristóteles de poiesis, el elogío de Iris Murdoch a el arte en tiempos palabras clave: crítica del arte; historia del no religiosos y el apelo de Giorgio Agamben a la unión entre poesía y filosofía. Defiendo, además, que gran parte de la crítica moderna se ha olvidado de la vocación conceptual original del arte y propongo métodos de evaluación en si mismo artísticos. 
1. BENJAMIN, Walter. Goethe's Elective Affinities. Ed. by Rolf Tiedemann and Herman Schweppenhauser. Frankfurt: Suhrkamp, 1974, p. 298.

2. WILDE, Oscar. The Artist as Critic: Critical Writings of Oscar Wilde. Ed. by Richard

Ellmann. Chicago: The University of Chicago Press, 1969, p. 384.

3. MURDOCH, Iris (1977). The Fire and The Sun: Why Plato Banished the Artists. Oxford: Oxford University Press, 1977. p. 36.

4.SALTZ, Jerry . The Tyranny of Art History in Contemporary Art. 2016. http://www.vulture. com/2016/09/tyranny- of-arthistory-in-contemporary-art. html. Accessed: April 23, 2019.

5. See the 2016 exhibit The Keeper at the New Museum, New York. https://www. newmuseum.org/exhibitions/ view/ the-keeper. Accessed:

August 8, 2018]

\section{Why Other Stories?} One may compare [the critic] to a paleographer in front of a parchment
whose faded text is covered by the lineaments of a more powerful script
which refers to that text. As the paleographer would have to begin by reading
the latter script, the critic would have to begin with commentary.

Walter Benjamin

[Art criticism of the highest kind] treats the work of art simply as a startingpoint for a new creation. It does not confine itself-let us at least suppose so for the moment - to discovering the real intention of the artist and accepting that as final. And in this it is right, for the meaning of any beautiful created thing is, at least, as much in the soul of him who looks at it, as it was in his soul who wrought it. Nay, it is rather the beholder who lends to the beautiful thing its myriad meanings, and makes it marvelous for us, and sets it in some new relation to the age, so that it becomes a vital portion of our lives, and a symbol of what we pray for, or perhaps of what, having prayed for, we fear that we may receive.

Oscar Wilde ${ }^{2}$

Why Other Stories? Art History is a fiction. The teleological organization of art 'movements,' one building on another, as if all art progressed to an idea of perfection (though we do not admit what that might be) is a fictional tool. The very grouping of artists and art works into categories, the inevitable exclusion of artists that do not fit such categorizations, the infinite revisions of history to discover what we have previously excluded (usually women, people of color, techniques deemed inferior, non-European art), the reliance on the always shifting documentation, the need for a seminal figure, the progenitor artist from whom a group will follow, the co-option of art practice to the commodified logic of capitalism,the very fact that art has no discipline which ensures veracity (as Murdoch diagnoses, truth in art is notoriously hard to estimate critically ${ }^{3}$ ), these are all easily identifiable fictions.

A harder fiction to pinpoint is what we deem art. When Vladimir Nabokov drew butterflies he did so for scientific purposes, measuring their patterns, identifying species; when he arranged butterflies penises in glass plates his intent was to do taxonomic research, not to create art. ${ }^{4}$ Still his creations display an aesthetic intelligence equal of that of the best abstract painters, so much so that the New Museum exhibited the 'sculptured sex' plates in an art show. ${ }^{5}$ Why do we call art only the object created with the intention of being art?

Art museums try to give art a safe home. This appears to be a noble goal, notwithstanding its known profane dimensions. In the same way, 
art history and art criticism try to render the arts intelligible. However, the discipline has yet to develop a sufficiently critical understanding of its methods and reasons. In art history the unpopularity of teleological thought as an object of critical inquiry exists in inverse proportion to the abundance of its use as a hermeneutic tool. Still, scholarship's tricks of the trade are widespread: endless digressions, commanding footnotes, the resort to citations and examples to qualify a point, the affectation of seriousness, blind belief in visual analysis. Which raises questions about our response to art: what are the critical demands placed upon the critic or academic who interprets art, what are the commitments of criticism to the philosophy of the time, what is the relationship between art criticism and art history. The study of art is an equalizer, albeit negatively so in the ways it is usually exercised: where different art forms are made one by the same unfortunate limitation of having to translate the wonder of art into interpretative language (emphasis on language). These problems all lead to the idea of fiction.

Yet Art History and Other Stories is a defense of fiction:

She read modern fiction too. Always fiction. She hated to hear the word 'escape' used about fiction. She might have argued, not just playfully, that it was real life that was the escape. But this was too important to argue about. ${ }^{6}$

In the early 1980 s, the project of 'critical postmodernism' faced the problem of judgement but ultimately failed. Little headway was make theoretically. What was asserted was a suspicion, or consternation, with the very idea of critical judgement. ${ }^{7}$ Since then for many the very idea of the critic as an authority, the specialist discriminating on matters of art and culture has become problematic, some favoring instead that academic inquiry can be a kind of cultural act in its own right: Alexander Nemerov, Art History professor at Stanford University has said 'I am an artist and my medium is scholarship.' ${ }^{8} \mathrm{Up}$ to the 16 th century, there was no clear boundary between good and bad taste, no correct way to understand art. In the 17 th century, French philosopher Jean de la Bruyere defined what he deemed a man of taste, one that grasps the point of perfection ${ }^{9}$ that is characteristic of every work of art, inaugurating the institutionalization of art criticism, which to some extent invariably excludes those without the 'correct' taste from connecting to a work of art.

Further the postmodernist legacy dispensed with the traditional
6. MUNRO, Alice. Too Much Happiness. Canada: McClelland and Stewart, 2009. p. 122.

7. See Round Table: The Present Conditions of Art Criticism, October, 100 (Spring 2002), pp. 200-228. See also OSBORNE, Peter. Anywhere or Not at All? Philosophy of Contemporary Art. London: Verso, 2013; ELKINS, James. What Happened to Art Criticism?. Chicago: Prickly Paradigm Press, 2003; MCQUILLAN, Martin. Posttheory: New Directions in Criticism. Edinburgh: Edinburgh University Press, 1999.

8. VALLADARES, Carlos. Alexander Nemerov: Stanford's Art History Preacher. 2017. www. stanforddaily.com/2017/ 04/07/nemerov-magazine/. Accessed: April 23, 2019.

9. AGAMBEN, Giorgio. The Man Without Content. Trans. by Georgia Albert. Stanford University Press, 1994, p. 10. 
10. CESARE, Nikki T. After Criticism: New Responses to Art and Performance. Ed. by Gavin Butt. Malden, MA: Blackwell Publishing, 2005,

p 3.

11. MCQUILLAN, Martin (ed.).

Post-theory: New Directions in Criticism. Edinburgh: Edinburgh University Press, 1999, p. 9.

12. ADORNO, Theodor W. Aesthetic Theory. Vol. 88. Theory and History of Literature. Minneapolis: University of Minnesota Press, 1997, p.1

13. In Untimely Meditations, when trying to define the present, Nietzsche writes: 'This meditation... is untimely, because I am here attempting to look afresh at something of which our time is rightly proud - its cultivation of history - as being injurious to it, a defect and deficiency in it; because I believe, indeed, that we are all suffering from a consuming fever of history'. NIETZSCHE, Friedrich.

Untimely Meditations. Ed. by Daniel Breazeale. Trans. by R.J. Hollingdale: Cambridge University Press, 1967, p. 60.

14. BARTHES, Roland; HEATH, Stephen. Image Music Text. New York: Hill and Wang, 1977, p. 10. critic that analyzed in the name of universal human values, instead valuing cultural difference: Marxism, feminism, post-structuralism, post-colonialism are some of the preferred new methods. Absolute statements were exchanged for deconstructive readings. As such,

there was thus no critical 'position' as such to occupy, no anterior vantage point set apart from criticism's object from which the task of critique could be launched: the postmodernist critic found herself always already imbricated in the warp and weft of the cultural text. ${ }^{10}$

A notable consequence of the postmodern legacy has been the diminishment of theoretical consideration amongst critics both inside and outside of academia, and an ever increasing distance between the academic disciplines of art history and philosophy. The editors of Post-theory described such theoretical hallowing rather austerely:'[in a] sclerosis of theoretical writing, the hardening of [its] lexical and syntactic arteries... the words and phrases which are combined in overfamiliar ways and thereby banalized, degraded, wielded like a fetish... in order to semaphore that 'Theory' is taking place are the surest sign that anything worthwhile is not." ${ }^{\prime 1}$ A similar final judgement was proclaimed by Adorno: 'it is self-evident that nothing concerning art is self-evident any more, not its inner life, not its relation to the world, not even its right to exist.' 12

This points to a flawed procedural attitude at the heart of how we understand art: the idea, held by many art historians and critics, that their studies represent a progressive understanding of art, an evolution from crude ignorance towards more refined wisdom. The actual cases where this is true are rare.

Another ever-more problematic concept is that of history itself. Nietzsche called the historical culture a disease ${ }^{13}$ Barthes, hysterics: 'History is hysterical: it is constituted only if we consider it, only if we look at it - and in order to look at it, we must be excluded from it. As a living soul, I am the very contrary of History, I am what belies it, destroys it for the sake of my own history (impossible for me to believe in 'witnesses'; impossible, at least, to be one; Michelet was able to write virtually nothing about his own time).'14

Of course it is not a particularly new proposition to discuss the impossibility of history. However, periodization matters particularly in the definition of contemporary art, since its only distinctive trait so far theoreticized is that of contemporaneit $y^{15}$, meaning that its determination 
elucidates the period only in relation to other phenomena, which does not amplify the work's phenomenal importance in itself. Agamben points to the inevitable disjunction through which we relate to such contemporaneity, because 'the entry point to the present necessarily takes the form of an archeology... the present is nothing other than [the] unlived element in every thing that is lived. Our time, the present, is in fact not only the most distant: it cannot in any way reach us. ${ }^{16}$

historical frame has been shown, time and time again, as open to bias: one of the great essays by Linda Nochlin, Why Are There No Great Women Artists? contends with the historical problematics of the historical nurturing women artists and the egregious fallacy of an art history that for so long did not account with their work. The 'fallacies' of art history are too many to cite. Still, the historical desire to categorize, group and define continues to negatively dictate much of the response to art, both in academia, museums, and in the personal responses to art. In front of a work of art, one tends to look for historical (and art historical) clues to guide a reaction, curbing and manipulating any possible emotional response to the work.

Finally, we must contend with the form that both art history and criticism are mainly practiced in: writing. The writerly act generates philosophical and viewpoint bias. It is particularly problematic in contemporary times because of the ever more diminutive attention given to the study of the disciple of Rhetoric. We can trace the problematics of writing to Plato, who distrusted it. Iris Murdoch explains Plato's objections well: 'indirectness and irony prevent the immediate relationship with truth which occurs in live discourse; art is thus the enemy of dialectic. Writing and painting introduce an extra distancing notation and by charm fix it in place. They create a barrier of imagery which arrests the mind, rigidifies the subject-matter, and is defenseless against low clients. ${ }^{17}$ Plato and the Greeks instead valued the spoken word, studying its metrical movements with scientifically minute care in ways that are not done today. The diminishing of the study of rhetoric and the tropes of written compositions have, in turn, created practitioners of art writing that are not masters of its tools.

This is what Oscar Wilde meant when he claimed it is the Greeks who have given us the whole system of art-criticism, and how fine their critical instinct was, may be seen from the fact that the material they criticized with most care was... language'. ${ }^{18}$ Wilde, not
202

Luiza Esper Berthoud

Art History and other stories

15. Giorgio Agamben has the best proposition (however open endedl about what contemporaneity means. See his lecture at the European Graduate School on April, 2017. https://www.youtube. com/watch?v=GsS9VPS_gms (accessed November 16, 2017)

16. AGAMBEN, Giorgio. Nudities. Trans. by David Kishik, and Stefan Pedatella. Stanford: Stanford University Press, 2011.

17. MURDOCH, Iris (1977). The Fire and The Sun: Why Plato Banished the Artists. Oxford: Oxford University Press, 1977. p. 37.

18. WILDE, Oscar. The Artist as Critic: Critical Writings of Oscar Wilde. Ed. by Richard Ellmann. Chicago: The University of Chicago Press, 1969, p. 11 
19. WILDE, Oscar. The Artist as Critic: Critical Writings of Oscar Wilde. Ed. by Richard Ellmann. Chicago: The University of Chicago Press, 1969, p. 18.

20. Ibidem, p. 20.

21. Sontag, in Against Interpretation, in place of a hermeneutics we need an erotics of art.' Another example: Hegel's Phenomenology is written in a dramatized manner that provides a case study of how scholarship and individual style can be used to expose philosophical thought. unlike Plato, believed in intellectualism, the view that humanity could be saved mainly through thinking, and as such for Wilde the highest form of art was writing, or literature. His preference for the written form also inspired in him an appreciation for written responses to art that made him value the critical practice even higher than the art it reflected upon. More interestingly, it led Wilde to defend a criticism that was poetic in form ('criticism is itself an Art' and 'I would call criticism a creation within a creation'19) and that understood that truth was not its goal, since its very idea is a fiction, but the goal instead was a response written 'with intellectual and emotional utterance, with lofty passion and with loftier thought, with imaginative insight, and with poetic aim... Who... cares whether Mr. Pater has put into the portrait of Mona Lisa something that Leonardo never dreamed of?'20

If criticism - meaning the discipline and, amply, every spectator's response to art - can rise above contingent opinion and fact collecting, if it can effectively remain meaningful, it has to find a new mode of working freed from the institutionalized postmodernist dystopia, from the Kantian idea of disinterested art (which inaugurated the dispassionate response modern audiences have to art) and from the post-conceptual field that remains unable to grasp contemporary art philosophically. Art History and Other Stories proposes that criticism can instead be a poietic response, a wondrous exercise that aims not for truth, that being distinct from knowledge, but instead to increase the mist around the work of art. Such is what Wilde defended, such is what Sontag called for in her preference for an erotics of art $^{21}$, such is what Agamben arrived at in his experimental book Idea of Prose that mixes poetry and criticism, such is what Goethe exercised when he reimagined a Greek cow statue from which survived no copies (more on this below), such are the novels of Chris Kraus that are both diary and profoundly insightful pieces of art criticism.

The argument I want to make in this article is both different and in some ways a mirror image of the familiar account dramatized by Wilde. I am interested in select examples of critical responses to art that instead of predicating on the Platonic suspicion about art, attempt to create a poetic response that mirrors the experience of art making. I will argue that there is a possibility of a response to art that marries poetry and philosophy (to use Agamben's terminology), with implications for both art making and for how we write about art. By 
returning to the frontiers of Aristotelian thought, we can come to a new understanding of how the fictions about art have shaped the discipline of art history.

\section{The Critic as Artist}

Poetry possesses its object without knowing it while philosophy knows its object without possessing it.

Giorgio Agamben ${ }^{22}$

Around 400 B.C.E., Myron, a highly-regarded Attic artist, created a cow made out of bronze, supposedly commissioned after the peace-treaty of Nicias with Sparta and dedicated on the Athenian acropolis. This statue has since been the subject of numerous epigrams and ongoing critical fascination, even though no reliable copies of the original statue have survived. The little evidence we have of the sculpture consists of a series of thirty six ecphrastic epigrams, most of which are amusements about the sculpture's life-likeness, so much so as to have deceived real bulls, birds and shepherds alike. Some of the beholders declaimed that the sculpture had to have been modeled after a real cow; or perhaps that underneath the bronze lay indeed the body of an actual cow; or, even more imaginatively, that Myron had deceived nature, conquered it. One example of a particularly inspired epigram attributed to Anakreon reads: 'Myron feigned a cow with his own hands which was not formed in molds, but which turned to bronze through old age. (Anth. Gr. 229.11 (no. 716)'.

Both the lost sculpture and, perhaps more significantly, the long tradition of ecphrastic epigrams that memorialized it, have become symbols for the limits of scholarship and of art criticism. How does one write about a sculpture one has never seen nor will ever see? There are many examples of jugglery that critics and scholars have performed to praise the sculpture, an exercise that usually dismisses the epigrams written, at least in part, by an audience that might have actually viewed the statue. The most absurd example of such criticisms was written by esteemed author and statesman Johann Wolfgang von Goethe, who published a short essay on the subject simply titled 'Myron's Cow.'23 To describe it briefly, the essay is a skeptical and ultimately erroneous re-imagination of the sculpture, which culminates with the author reaching a very creative conclusion, deemed by Goethe as the only
22. AGAMBEN, Giorgio. Stanzas: Word and Phantasm in Western Culture. Vol. 69. Theory and History of Literature. Minneapolis: University of Minnesota Press, 1993, p. xvii.

23. I have used the translation of the essay published in The Essential Goethe, by Matthew Bell. Princeton \& Oxford: Princeton University Press, 2018, pp. 903-908. 

of the sculpture could not have been a cow, but instead a cow and a nursing calf.

What reasons might have lead the writer towards such extreme proposition expose the dominant paradigms about classical art during the 18th century, but also prove art history's methodological limits in general, the problematic of what is an art object, and, more interestingly, the creative powers of good art critics.

We can ascertain that art and the attempt to comment on it has always existed. The relationship between art and the collective or institutionalized understanding about art has not been resolved. It is that very relationship that troubled Plato, who saw art's propensity to incite false knowledge. Agamben also sees trouble in how we respond to art, albeit in a symmetrically opposite manner than Plato: if the Greek was worried about the spectator's direct engagement with art, Agamben diagnoses that since the positioning of men specialized in the matters of good taste and judgement as commentators and intermediaries, the true relationship between viewer and art has been impeded. Still, both philosophers question how one engages with art. Does it involve a certain expectation of what an artwork must be (a source of knowledge, pure beauty, emotional engagement, etc)? It is disconcerting to think about how an object fits into the rubric of art history because it questions the very foundations of the discipline. And if most criticism and academic writings about art are almost always faulty, problematic and impeding (as Agamben argues), how should we relate to all the knowledge created about art?

To return to Myron's cow: is Goethe's ultimate mistake regarding the sculpture an example of Agamben's theories, that the specialized study of art is deficient? Agamben himself proposes that a creative engagement (a poetic response) to art is possible and favourable. Under this rubric, could Goethe's essay be deemed a successful example of criticism because of its failings, meaning that his re-imagination of the cow and calf is actually a creative, inventive, and, yes, fictional response to a work of art he had never seen. If the answer is positive, Goethe's essay could be deemed a poetic response, this conclusion would still be ambiguous, because Goethe himself condemns the poetic flourishing of the epigrammatic tradition. He specifically writes against 'the misleading attributes with which poets tried to embellish the 
statue (perhaps without have ever seen it,) ${ }^{24}$ a proclamation deliciously hypocritical considering Goethe's own imaginative embellishments.

It is clear that Goethe searched for fixed principles in classical art because, consistent with the philosophy of his time, he correlated moral values to formalism. His understanding of mimesis and naturalism ignored a more robust understanding of the dialectic between making and viewing that can be found in the Greek art tradition as it is understood today. Ultimately, Goethe rejected the autonomy of creativity from philosophy, an idea much explored by Agamben. Despite such 'failings,' Goethe's essay provides an opportunity for a true appreciation of the sculpture, an important contribution since the work has been long lost and no copies have survived. Even though Goethe mostly rejects the epigrams connected to Myron's cow, he, in his essential mistake, ends up relating to the work in the same way the creators of the ecphrastic epigrams did: not in the Platonic manner, as higher degrees of mimesis that separates us from the original artist's intent, but through apt and participatory mechanisms, engaging in a relationship with the art that is uninterested in theoretical certainty or connoisseurship (be that by choice or by mistake). As such, both Goethe's essay and the epigrams may be described as examples of engagement with a work of art through a form of poetic exercise.

Goethe's self education on classical art is documented in minutiae (or rather in self-editorialized minutiae) in the book Italian Journey. In the letters to his close friend and fellow writer Charlotte von Stein selected to be in the book, Goethe finally in Rome studying art describes himself as 'reborn' and 'newly educated' by his journey. His mention of rebirth echos the Renaissance rediscovery of classical ideas. Similarly, his discovery of Ancient Greece would occur through the intermediate vessel of 18th century's Italy. He mentions the 'Greek nature' of the Italian people's customs and culture: he sees the Odyssey embodied in a Venetian beggar; or the Italian mode of speech as mirroring the rhetoric of Greek tragedies. In these ways it was not Ancient Greece that Goethe discovered in his journey, but modern Italy.

It is then important to determine to what extent Goethe regarded what he encountered in Italy as equivalent to the Ancient Greek tradition of philosophy and art. He associates values of grandeur and truth that he sees in ruins and Classical philosophy with the works of 'the ancients.' On multiple occasions Goethe writes with the ambiguous 
25. TREVELYAN, Humphry.

Cambridge University Press.

London: Wiley-Blackwell, 1942, p. 123.

26. GOETHE, Johann Wolfgang von. Italian Journey. Trans. by Robert R. Heitner. New York: Suhrkamp Publishers, 1989, p. 279.

27. Ibidem, p. 15.

28. Ibidem, p. 279 .
Roman architectural constructions such as the Amphitheatre at Verona and the aqueduct near Spoleto, and generalises his impressions into lofty conceptions about 'the ancients.' He does not appear to know that the Greeks had not known such giant structures, and at that time, 'examples of Greek architecture were practically unknown- even the temples of Paestum, only sixty miles from Naples, had hardly begun to attract attention... Goethe used Palladio as guide in architectural matters, who founded his practice on that of "the ancients," but to whom the Greek Doric with its sturdy proportions was unknown.'25

Goethe sought an education on art in order to feed his creative genius, the way to escape what he deemed his long-enduring 'fate of Sisyphus and Tantalus. ${ }^{26} \mathrm{He}$ believed his futile day-to-day labor and the knowledge he longed for could be overcome through a Renaissancelike desire for truth. At the beginning of the journey, Goethe admits to his ignorance on art: 'In the hall of classical sculpture I could soon tell that my eyes were not trained to appreciate such objects and so did not want to stay and waste time. Most pieces did not appeal to me at all, though I could not have said why'27. It is important to note Goethe's search for the 'true purposefulness' of ancient art - one that interprets Nature with a simplicity and accuracy as the ancients had done - was a goal he sought to achieve in his own writing. He notes:

[If] one can immediately turn again to nature, and find and gather again what those men found and more or less imitated, that surely has to expand the mind and finally give it the highest intuitive concept of nature and art. I shall not rest until everything that is still merely words and tradition for me becomes a living concept. 28

Overall, three main assumptions in the Myron's Cow essay essentially lead Goethe astray, many of which could produce interesting studies particularly regarding how Ancient Greek scholarship has been formed:

i. A conflation, in concept, of Art and Nature to be found in Goethe's particular understanding of mimesis and naturalism.

ii. A mystifying reverence for historical categorization, one certainly derived from Winckelmann, who established for Goethe, the guiding tradition of scholarly investigation into ancient art. But mystifying because in the essay on Myron's cow, Goethe's arguments are based much more on 
intuition than on what we would deem strict reasoning, methodology or observation.

iii. Due to Goethe's personal goal of improving his artistic practice, every conclusion reached about ancient art was also made to suit his modern needs.

Particularly regarding his view on historical categorization, Goethe writes on January 28, 1787 :

Rome possesses enormous riches, but they are all in ruins, and in the case of every object I feel called upon to determine the era which produced it. Winckelmann ungently spurs us on to separate the epochs, to recognize the various national styles, which in the course of time were gradually developed and eventually spoiled. Every true art lover became convinced of this. We all acknowledge the justice and importance of the demand.

But how to obtain this insight! Little preliminary work has been done. While the concept has been correctly and magnificently put forward, the individual details are obscure and uncertain. It requires years of thoroughly training the eye, and one must learn before one can ask. It is useless to waiver and hesitate, for attention is now actively being given to this important point, and everyone who takes the matter seriously can see that no judgement is possible in this field unless it can be developed historically.

The second thought is concerned exclusively with the art of the Greeks and aims at discovering how those incomparable artists went about developing their circle of godly figures - which is perfectly complete and lacing neither any main features nor the transitions and intermediate stages - of the human form. My supposition is that they proceeded according to the same laws by which nature proceeds, and which I am tracking down. But something else is involved that I cannot put into words. ${ }^{29}$

It seems then necessary to establish the mentioned essay titled 'Myron's Cow.' The review is studied here as a paragon of modern criticism of art; however not a lot of information is available regarding its purpose, audience or source of publication. The short essay appears to have been self-published by Goethe in 1818 on a supposedly artreview style pamphlet, though the information about this is lacking. The date shows us that Goethe had already finished his Italian travels by the time of the publication, thus much of his education on classical art was by then advanced.

It was also accompanied by an illustration by K. A. Schwerdeburth and commissioned by Goethe himself, thus imagined in such a way as to fit his own conclusions about the cow and calf (see figure 1 below). The engraving shows a cow nursing a calf, both animals' bodies positioned mid-movement, the calf kneeling on its front paws so as to nurse, while the cow's neck is sideways so that its head permits

29. GOETHE, Johann Wolfgang von. Italian Journey. Trans. by Robert R. Heitner. New York: Suhrkamp Publishers, 1989, pp. 136-7. 
30. See SPEYER, Wolfgang. Myron's Kuh in der antiken Literatur und bei Goethe. Arcadia 10, n.2, 1975, p. 174. 'The numerous epigrams on Myron's Cow try in ever new turn to express the deceptive natural similarity of this work of art.'

31. Endres identifies Goethe's essay as a paragone with Myron's cow sculpture and its literary descriptions - a paragone that transforms the 'representation of detail' ascribed to Myron's cow by a formerly unknown 'detail of its representation:' the nursin

Figure 1: Carl August Schwerdgeburth, Myron's Kuh, from Ueber Kunst und Alterthum 2 (1818):

frontispiece, engraving, $14.2 \mathrm{X}$ $8.4 \mathrm{~cm}$ lartwork in the public domain; photograph from Klassik Stiftung Weimar.]

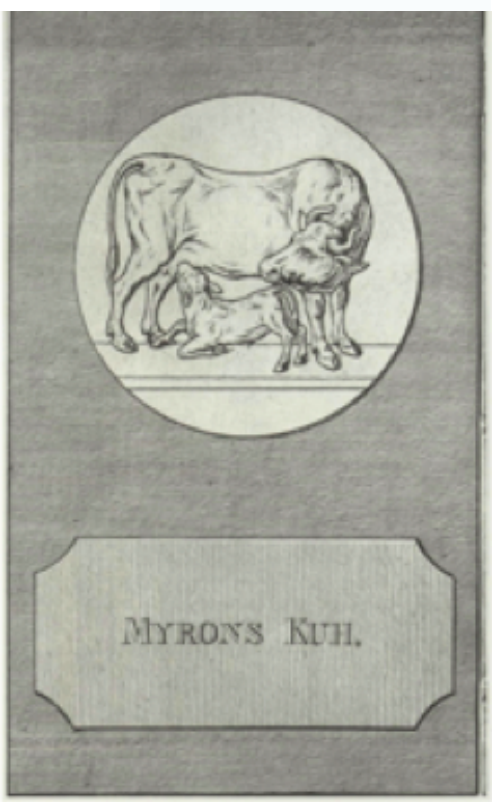

a view of the calf. The details of musculature and proportion in the animals' bodies are reminiscent of the classical style and demonstrate Goethe's understanding, and preference, for what ancient Greek art should look like. It is a beautiful visual representation that evokes the talents attributed to Myron of which we have become accustomed to it is also, of course, a completely fictional rendering, based on little to no evidence.

The epigrammatic tradition that has survived Myron's original statue and its relation to Goethe's essay has been studied sparsely, most notably by Wolfgang Speyer in 1975 in the short essay 'Myron's Kuh in der antiken Literatur und bei Goethe; ${ }^{30}$ by Johannes Endres in 2012 on the again short essay 'Notes From the Field: Detail;' ${ }^{31}$ and lastly by Michael Squire in the article 'Making Myron's Cow Moo,' though Goethe's essay was not the focus of the latter, but rather the epigrammatic tradition related to the sculpture.

Considering, then, the lack of writing or evidence relating to the original sculpture, Goethe's premise when studying the subject becomes particularly confounding: that the thirty-six Greek epigrams that describe Myron's bronze sculpture of a cow, the only material evidence that survive the statue, should be dismissed:

\begin{abstract}
About 400 BC, a Greek sculptor named Myron made a bronze cast of a cow. Cicero reports having seen the statue in Athens, and in the seventh century Procopius saw it in Rome. Thus, for over a thousand years the work had attracted attention. Although considerable information concerning this statue has come down to us, none of it is of much help in forming a clear idea of the original. Even more surprising is the fact that some thirty-six epigrams on the subject are not more useful in this respect either and are only worth of note as examples of the kind of confusion which poetically inclined viewers can cause. These epigrams are dull and neither descriptive nor informative, and for this reason tend to be more misleading than helpful when used as a basis for visualizing and defining the lost bronze. The named and unnamed authors seemingly tried to outdo each other in producing rhythmic pleasantries rather than address themselves seriously to the work itself. The best they can say is that they feel compelled to extol the statue's remarkable realism. But such praise by dilettantes is highly suspect. ${ }^{32}$
\end{abstract}

The epigrams were produced both contemporaneously by sources who would have seen the statue, and also by some who probably never had the chance to see neither the statue nor a reliable copy, as it is common in the ecphrastic calf whose attachment to the overarching principle of life, in Goethe's eyes, can free artistic mimicry from the lowering notion of the base subject in classical art epigrammatic 
tradition. As such, there are poets, like Posidippus and Leonidas who specialized primarily or exclusively in epigrams. Other authors, like Callimachus and Theocritus were better known for their work in other genres, but also composed significant quantities of epigrams. Gutzwiller typifies epigrams as 'the most characteristic of Hellenistic poetic form. ${ }^{33}$

The successive anthologies which compiled the epigrams from the late Hellenistic era and after the Byzantine era strongly altered the hermeneutical approaches applied to the interpretation of the epigrams by directing a sequential reading of the poems. This approach often left the epigrams out of context, and it might be one of the reasons that some modern scholars see the epigrams as little variations on the same idea to be read successively. A similar criticism is echoed by Goethe in the excerpt above, and it appears central to his disinterest towards the Myron's cow epigrams.

Another identifiable problem with studying the epigrams is that little time has been spent on the literariness of the tradition. It seems that the medium's obvious brevity has led many scholars, including Goethe, to assume a prejudicial view of it. There are not many studies on the stylistic variations, nor explorations about the levels of poeticity in diction and imagery. The epigrams' capacity for meaning, be it literary, philosophical or political, is usually ignored, and a mimetic expectation seems to be the only avenue proposed: Squire deems the thirty six poems on Myron's cow an 'ecphrastic project of replicating images in words.'34

To cite one more of Goethe's assumed fallacies: he characterizes the cow as a 'base subject,' one of his main justifications for the necessity of a calf near it, because he forgets the tradition of votive offerings common on the Acropolis. A cow was the second most valuable animal to sacrifice (behind a bull), and it would have been a fit subject for Athena, since female animals were often often sacrificed to female deities. However, this is not the focus of this thesis and I will not dwell on it further.

The interest here, instead, is that Goethe, albeit indirectly, addresses one of the most important questions regarding criticism of a work of art, a question that is still a source of trouble in art history: how do we know art? The system of criticism, and the art world's shifting alliances with it, rest on the relationship between what one understands
32. BELL, Matthew. The Essential Goethe. Princeton and Oxford: Princeton University Press, 2018.

33. GUTZWILLER, Kathryn J. Poetic Garlands: Hellenistic Epigrams in Context. Berkeley: University of California Press, 1998, p. 3.

34. SQUIRE, Michael. Making Myron's Cow Moo?: Ecphrastic Epigram and the Poetics of Simulation. American Journal of Philology (Johns Hopkins University Press) 131.4, 2010. 

as Aristotle counter-argues) and what one understands as the correct response to art (formalist and diagnostic or poetic and possibly fictionalised).

Oscar Wilde beautifully argues that art critics have always existed, meaning that has been no instance of a 'pure,' direct engagement with art at least since Antiquity:

My dear Ernest, even if not a single fragment of art criticism had come down to us from Hellenic or Hellenistic days, it would be none the less true that the Greeks were a nation of art critics, and that they invented the criticism of art just as they invented the criticism of everything else. For, after all, what is our primary debt to the Greeks? Simply the critical spirit. And, this spirit, which they exercised on questions of religion and science, of ethics and metaphysics, of politics and education, they exercised on questions of art also, and, indeed, of the two supreme and highest arts, they have left us the most flawless system of criticism that the world has ever seen. ${ }^{35}$

as Critic: Critical Writings of Oscar Wilde. Ed. by Richard Ellmann. Chicago: The University of Chicago Press, 1969, P. 8

36. MURDOCH, Iris. The Fire and The Sun: Why Plato Banished the Artists. Oxford: Oxford University Press, 1977.

Wilde does not ultimately define the methodology of such a system of criticism. He expects from the critic adherence to universal conceptions of beauty and a response that is itself beautiful. Iris Murdoch reaches a parallel conclusion about art criticism, and of course her own work undulates between romance novels and philosophical treatises. She writes: 'There is no science of criticism; any so-called critical system of art has in the end to be evaluated by the final best instrument, the calm open judging mind of the intelligence experienced critic, unmisted, as far as possible, by theory. ${ }^{36}$

Despite Goethe's dismissal of the thirty-six epigrams as the labor of 'dilettantes' with 'empty rhetorical flourishes' (even though he still goes on to nitpick three epigrams to use as proof for his own theory), I propose instead that the epigrams are proof of a engagement with the work of art that is not concerned with uncovering 'truths' about the object, but rather responses from an audience that engaged in a more personal and creative relationship to the work. The epigrams, then, could be studied as creative, artistic pieces themselves, a form of response that is set in motion by another work of art's own creativity and vision. And artistry needs not be the only attribute present in these responses, for they are also rich with philosophical considerations.

This positioning of the epigrams, and even of Goethe's essay, as examples of poetic responses to art invoke, as briefly mentioned before, 
the work of Giorgio Agamben. The philosopher's main argument is articulated below:

When the term 'criticism' appears in the vocabulary of Western philosophy, it signifies... inquiry at the limits of knowledge about precisely that which can be neither posed nor grasped. If criticism, insofar as it traces the limits of truth, offers a glance of truth's homeland like an island nature has enclosed within immutable boundaries, it must also remain open to the fascination of the wide and storm-tossed sea that draws the sailor incessantly toward adventures he knows not how to refuse yet may never bring to an end. ${ }^{37}$

Similarly to Wilde who spoke of an ideal criticism and was condemnatory of the journalistic tendencies of the literary criticism of his time, Agamben prescribes to the ideal criticism the character of being a creative pursuit. He identifies modern criticism to the work of art as a "methodology with nothing left to cut - namely, the realization that the object to have been grasped has finally evaded knowledge.'38

The reason criticism cannot possess the object of knowledge is a scission at the heart of Western thought, a schizophrenic division between 'inspired-ecstatic and rational-conscious poles.' Agamben defines the scission clearly:

Between poetry and philosophy, between the poetic word and word of thought... that poetry possesses its object without knowing it while philosophy knows its object without possessing it. In the West, the word is thus divided between a word that is unaware, as if fallen from the sky, and enjoys the object of knowledge by representing it in beautiful form, and a word that has all seriousness and consciousness for itself but does not enjoy its object because it does not know how to represent it. ${ }^{39}$

This distinction is also one between knowledge and wonder. Poetry, although unaware of it, is always an attempt towards knowledge; while philosophy is equally unaware that its every act is an attempt towards wonder.

Where does criticism fall in the dialectic? For Agamben, 'criticism can be expressed in the formula according to which neither represents nor knows, but knows the representation. To appropriation without consciousness and to consciousness without enjoyment criticism opposes the enjoyment of what cannot be possessed and the possession of what cannot be enjoyed. ${ }^{40}$ The failures of criticism are similar to those of modern art in its renouncement of the creative dimension in favor of a methodologically critical exercise that throughout
37. AGAMBEN, Giorgio.

Stanzas: Word and Phantasm in Western Culture. Vol. 69. Theory and History of Literature. Minneapolis: University of Minnesota Press, 1993, p. 15.

38. Ibidem, p. 16.
40. Ibidem, p. 17. 
41. MURDOCH, Iris. The Fire and The Sun: Why Plato Banished the Artists. Oxford: Oxford University Press, 1977.

p. 499.

42. FERGUSSON, Francis. Aristotle's Poetics. New York: Hill and Wang, 1961. history has degenerated into ever more lifeless expressions. To regain its power, then, criticism and the art history discipline in general must abandon the doomed positivist practice of progressive accumulation of knowledge and return to the frontier of a more creative pursuit.

Murdoch also makes similar considerations:

\begin{abstract}
Perhaps in general art proves more than philosophy can. Familiarity with an art form and the development of taste is an education in the beautiful which involves the often largely instinctive, increasingly confident sorting out of what is good, what is pure, what is profoundly and justly imagined, what rings true, from what is trivial or shallow or in some way fake, selfindulgent, pretentious, sentimental, meretriciously obscure, and so on... Bad art is a lie about the world, and what is by contrast seen as good in some important evident sense seen as ipso facto true and as expressive of reality... Learning to detect the false in art and enjoy the true is part of a life-long education in moral discernment. ${ }^{41}$
\end{abstract}

Goethe's essay, as well as much of modern criticism, are undeniably informed by the Platonic misgivings about art that Murdoch expertly dissects in the Fire and the Sun. It is essential to characterize Plato's puritanic views in terms of its connectedness, for him, with religion. This moralistic connection of beauty to goodness and virtue is central to his thought. Then, the main objections Plato raises are that art is not concerned with moral truth, and moreover that art purposefully undermines truth by appealing to the lowest part of the human soul. The supposed 'content' of a work of art, because it is so evasive, only offers obvious satisfaction without making a genuine assertion on morality or goodness. Aristotle disagreed, seeing in art more than imitation, as rather art as world-unveiling, world understanding.

On the first five chapters of Poetics Aristotle lays an important concept for this thesis' argument: that artists 'imitate action' in various ways. I have found that Fergusson has given the the clearest explanation about this concept: by 'action' Aristotle means not physical activity, but a movement of spirit, and by 'imitation' he means not mere copying, but the representation of the many forms which the life of human spirit may be activated in the arts, be it in music, painting, writing etc. ${ }^{42}$

Although many of the thirty-six epigrams comment on the illusionist quality of Myron's work, most of them do so not by associating it with the immorality at the center of Plato's argument, but rather in a positive way. In fact many of the beholders appear happy, joyful with the illusion, responding to it with wonder and playfulness. When the poets talk about Myron choosing not to give life to his magnificent cow, 
they say so to praise the superior talent of the artist and to embed the creative art with more than pure imitation of the Forms, but with the highest potentiality of human life, that is, to create as a mode of world understanding. For them the sculpture functions as a valuable aid to thought, and they engage with it as one who loves art would. Moreover, the authors of the epigrams were as informed of the facts regarding the sculpture, or more so, than any late inquirers. Through this view, the epigrams appear not as confused subjects of mimesis, but as a form of praise of and engagement with the artist, and the other writers of epigrams, for many epigrams are written as responses to each other. In this way, the epigrams are closer to the Aristotelian characterization of poetics, one that sees art as persuasive testament to the human capacity for poeticity.

Goethe's essay also touches on other fictions of art history mentioned in Chapter One. Echoing Winckelmann, who strove to reconstruct a visual description of the famous torso from its 'remnants,' it matters to Goethe that the art historian achieves an object's adequate depiction, investigating the work at every possible level to elicit a response from it, and ultimately restricting the art work to its material and visual presence. Another fiction is Goethe's own impulse to discipline unruly forces on his quest for the laws of art, a quest that ultimately frustrated him. By the end of his Italian trip, Goethe increasingly saw historical study as inhibiting rather than liberating

Interestingly, both Goethe and Winckelmann cast doubt on the fundamental ability of language to capture the aesthetic experience, instead recommending that a live and dynamic experience of art is preferable to the intellectual satisfaction at accounting for the history or style of a work. This appears to be a common conclusion to many critics of art, though few continue further on the thought, meaning: can the dynamic experience be expressed in writing in any way?

Again, Murdoch offers luminous thought (highlights are mine):

Plato says (Phaedrus, Letter VIII) that no sensible man will commit his thought to words and that a man's thoughts are likely to be better than his writings. Without raising philosophical problems about what a man's thoughts are, one may reply that the discipline of committing oneself to clarified public form is proper and rewarding: the final and best discoveries are often made in the actual formulation of the statement. The careful responsible skilful use of words is our highest instrument of thought and one of our highest modes of being: an idea which might seem obvious but is not now by any means universally accepted. ${ }^{43}$

$+$ 
How then should criticism be enacted? In Stanzas and years

ก. 38 later in Language and Death, Agamben proposes a criticism free of an object of inquiry, instead centered on potentiality itself. This is the idea that humans are potentially poetical beings that continually create and refashion themselves in the world. Agamben proposes that criticism could combine in one discourse the poetic and the philosophical approaches, creating what he deems to be 'the true human language.' 44 The philosopher also speaks of engaging in joy, eroticism, unreality and love by the embrace of the utopia and the void at the heart of every act of criticism. Against the traditional Western model of signifier and signified, art criticism should be constructed as a labyrinth, a form that requires a pilgrimage of closeness and distance to the center.

This innovative form of criticism has been enacted by few critics but by many artists, and most successfully so by contemporary writer and 'failed' artist Chris Kraus.

The complexity of art, its ambiguity and ubiquitousness, is not bodied forth solely in the object. Art history, institutions and criticisms that ignore this fact in their 'translations' of the work of art only reduce it to what's not essential to it, to what Nietzsche would call nothingness. The attempt to create and understand art is the highest mark of human freedom, the freedom to know thyself and the world, and this experience is too powerful to be channeled through Art history as we know it today. 


\section{References}

ADORNO, Theodor W. Aesthetic Theory. Vol. 88. Theory and History of Literature. Minneapolis: University of Minnesota Press, 1997.

AGAMBEN, Giorgio. Stanzas: Word and Phantasm in Western Culture. Vol. 69. Theory and History of Literature. Minneapolis: University of Minnesota Press, 1993.

AGAMBEN, Giorgio. The Man Without Content. Trans. by Georgia Albert. Stanford University Press, 1994.

AGAMBEN, Giorgio. Language and Death: The Place of Negativity. Ed. by Wlad Godzich and Jochen Schulte-Sasse. Trans. by Karen E. Pinkus and Michael Hardt. Vol. 78. Theory and History of Literature. Minneapolis: University of Minnesota Press, 2005.

AGAMBEN, Giorgio. Nudities. Trans. by David Kishik, and Stefan Pedatella. Stanford: Stanford University Press, 2011.

BARTHES, Roland; HEATH, Stephen. Image Music Text. New York: Hill and Wang, 1977.

BELL, Matthew. The Essential Goethe. Princeton and Oxford: Princeton University Press, 2018.

BENJAMIN, Walter. Goethe's Elective Affinities. Ed. by Rolf Tiedemann and Herman Schweppenhauser. Frankfurt: Suhrkamp, 1974.

CESARE, Nikki T. After Criticism: New Responses to Art and Performance. Ed. by Gavin Butt. Malden, MA: Blackwell Publishing, 2005.

FERGUSSON, Francis. Aristotle's Poetics. New York: Hill and Wang, 1961.

GOETHE, Johann Wolfgang von. Italian Journey. Trans. by Robert R. Heitner. New York: Suhrkamp Publishers, 1989.

GUTZWILLER, Kathryn J. Poetic Garlands: Hellenistic Epigrams in Context. Berkeley: University of California Press, 1998.

MCQUILLAN, Martin (ed.). Post-theory: New Directions in Criticism. Edinburgh: Edinburgh University Press, 1999.

MUNRO, Alice. Too Much Happiness. Canada: McClelland and Stewart, 2009. 
MURDOCH, Iris. The Fire and The Sun: Why Plato Banished the

n. 38 Artists. Oxford: Oxford University Press, 1977.

NIETZSCHE, Friedrich. Untimely Meditations. Ed. by Daniel Breazeale. Trans. by R.J. Hollingdale: Cambridge University Press, 1967.

SALTZ, Jerry. The Tyranny of Art History in Contemporary Art. 2016. http://www.vulture.com/2016/09/tyranny- of-art-history-incontemporary-art.html. Accessed: April 23, 2019.

SPEYER, Wolfgang. Myron's Kuh in der antiken Literatur und bei Goethe. Arcadia 10, n.2, 1975, pp. 171-179.

SQUIRE, Michael. Making Myron's Cow Moo?: Ecphrastic Epigram and the Poetics of Simulation. American Journal of Philology (Johns Hopkins University Press) 131.4, 2010.

TREVELYAN, Humphry. Cambridge University Press. London: WileyBlackwell, 1942.

VALLADARES, Carlos. Alexander Nemerov: Stanford's Art History Preacher. 2017. www.stanforddaily.com/2017/ 04/07/nemerovmagazine/. Accessed: April 23, 2019.

WILDE, Oscar. The Artist as Critic: Critical Writings of Oscar Wilde. Ed. by Richard Ellmann. Chicago: The University of Chicago Press, 1969.

Luiza Esper Berthoud nasceu em Taubaté, em 1988. É escritora e mestre em História da Arte pela University of California, Davis. Foi pesquisadora bolsista no Yerba Buena Center for Arts (YBCA), museu e centro de pesquisa de arte contemporânea em São Francisco, Califórnia, instituição pela qual também publicou um conto sobre a condição do estrangeiro nos EUA. Atuou como assistente de curadoria

Artigo recebido em 20 de setembro de 2019 e aceito em 30 de março de 2020 . no Richmond Art Center, na Califórnia. Sua pesquisa em filosofia da arte é focada na impossibilidade da história da arte. 